\title{
Detrital zircons from the Ordovician rocks of the Pyrenees: Geochronological constraints and provenance
}

\author{
Aina Margalef ${ }^{\mathrm{a}, *}$, Pedro Castiñeiras $^{\mathrm{b}}$, Josep Maria Casas ${ }^{\mathrm{c}}$, Marina Navidad $^{\mathrm{b}}$, Montserrat Liesa $^{\mathrm{d}}$, \\ Ulf Linnemann $^{\mathrm{e}}$, Mandy Hofmann ${ }^{\mathrm{e}}$, Andreas Gärtner ${ }^{\mathrm{e}}$ \\ a Centre d'Estudis de la Neu i de la Muntanya d'Andorra, Institut d'Estudis Andorrans, Andorra \\ b Departamento de Petrología y Geoquímica, Universidad Complutense de Madrid, 28040 Madrid, Spain \\ c Departament de Geodinàmica i Geofisica-Institut de Recerca GEOMODELS, Universitat de Barcelona (UB), Martí i Franquès s/n, Barcelona 08028, Spain \\ d Departament de Geoquímica, Petrologia i Prospecció Geològica, Universitat de Barcelona (UB), Martí i Franquès s/n, Barcelona 08028, Spain \\ e Senckenberg Naturhistorische Sammlungen Dresden, Museum für Mineralogie und Geologie, Sektion Geochronologie, Königsbrücker Landstraße 159, D-01109 Dresden, Germany
}

\section{A R T I C L E I N F O}

Article history:

Received 31 August 2015

Received in revised form 9 March 2016

Accepted 14 March 2016

Available online $\mathrm{xxxx}$

\section{Keywords:}

Detrital zircon

Ordovician rocks

Upper Ordovician unconformity

Pyrenees

\begin{abstract}
A B S T R A C T
The first LA-ICP-MS U-Pb detrital zircon ages from quartzites located below (three samples) and above (one sample) the Upper Ordovician unconformity in the Central Pyrenees (the Rabassa Dome, Andorra) were investigated. The maximum depositional age for the Jújols Group, below the unconformity, based on the youngest detrital zircon population, is around $475 \mathrm{Ma}$ (Early Ordovician), whereas for the Bar Quartzite Fm., above the unconformity, the presence of only two zircons of 442 and 443 Ma precludes obtaining a precise maximum sedimentation age. A time gap of $\sim 20$ million years for the Upper Ordovician unconformity in the Pyrenees can be proposed, similar to that of the Sardic unconformity in Sardinia. The similar age patterns obtained on both sides of the Upper Ordovician unconformity suggest that there was no change in the source area of these series, while the absence of a Middle Ordovician age population may be due to a lack of sedimentation at that time. The four study samples present very similar U-Pb age patterns: the main age populations correspond to Neoproterozoic (Ediacarian-Cryogenian, ca. 550-750 Ma); Grenvillian (Tonian-Stenian, ca. 850-1100 Ma); Paleoproterozoic (Orosirian, ca.1900-2100 Ma) and Neoarchean (ca. 2500-2650 Ma). The similarity with the Sardinian age distribution suggests that these two terranes could share the same source area and that they were paleogeographically close in Ordovician times in front of the Arabian-Nubian Shield.
\end{abstract}

(c) 2016 Elsevier B.V. All rights reserved.

\section{Introduction}

Detrital zircon U-Pb geochronology is a powerful tool to determine the maximum depositional age for clastic sediments, to characterize potential provenance areas and to assess paleogeographic models, especially in areas where other methods, such as paleomagnetism or fossil distribution, cannot be used. After the early works by FernándezSuárez et al. (2000) and Linnemann et al. (2000), the age signatures of detrital zircons have been widely used in the European Variscan belt and in the basement rocks involved in the Mediterranean Alpine orogenic belt to determine the potential provenance areas for the metasediments and thus to assess Ediacaran-early Paleozoic paleogeographic models (see discussion in Avigad et al., 2012; Meinhold et al. 2013). Zircon age spectra have also been used to determine the

* Corresponding author at: Centre d'Estudis de la Neu i de la Muntanya d'Andorra, Institut d'Estudis Andorrans, Av. Rocafort, 21-23, 3a planta. Sant Julià de Lòria, Andorra.

E-mail address: amargalef.cenma@iea.ad (A. Margalef). maximum depositional age of the thick unfossiliferous lowermost preVariscan series (Díez-Fernández et al., 2012; Talavera et al., 2012) and to determine the time gap involved in certain unconformities in the Iberian Massif (Talavera et al., 2015).

We report the first detrital zircon ages from the pre-Variscan basement rocks of the Pyrenees, where a thick unfossiliferous metasedimentary sequence largely outcrops (Fig. 1). This sequence is covered by the Upper Ordovician unconformity and has been classically known as "Cambro-Ordovician", but recently Ediacaran-early Cambrian $\mathrm{U}-\mathrm{Pb}$ ages have been obtained for its lower part, and thus we prefer the term "pre-Upper Ordovician". We present LA-ICP-MS U-Pb detrital zircon age data from both pre-Upper Ordovician and Upper Ordovician rocks from Rabassa Dome in the Central Pyrenees. The results presented here enable us to discuss (1) the maximum depositional age of the uppermost part of the pre-Upper Ordovician sequence, (2) the time gap involved in the Upper Ordovician unconformity, and (3) the lower Paleozoic paleoposition of the Pyrenean basement rocks. Comparisons with previous proposed reconstructions allow us to obtain a more 


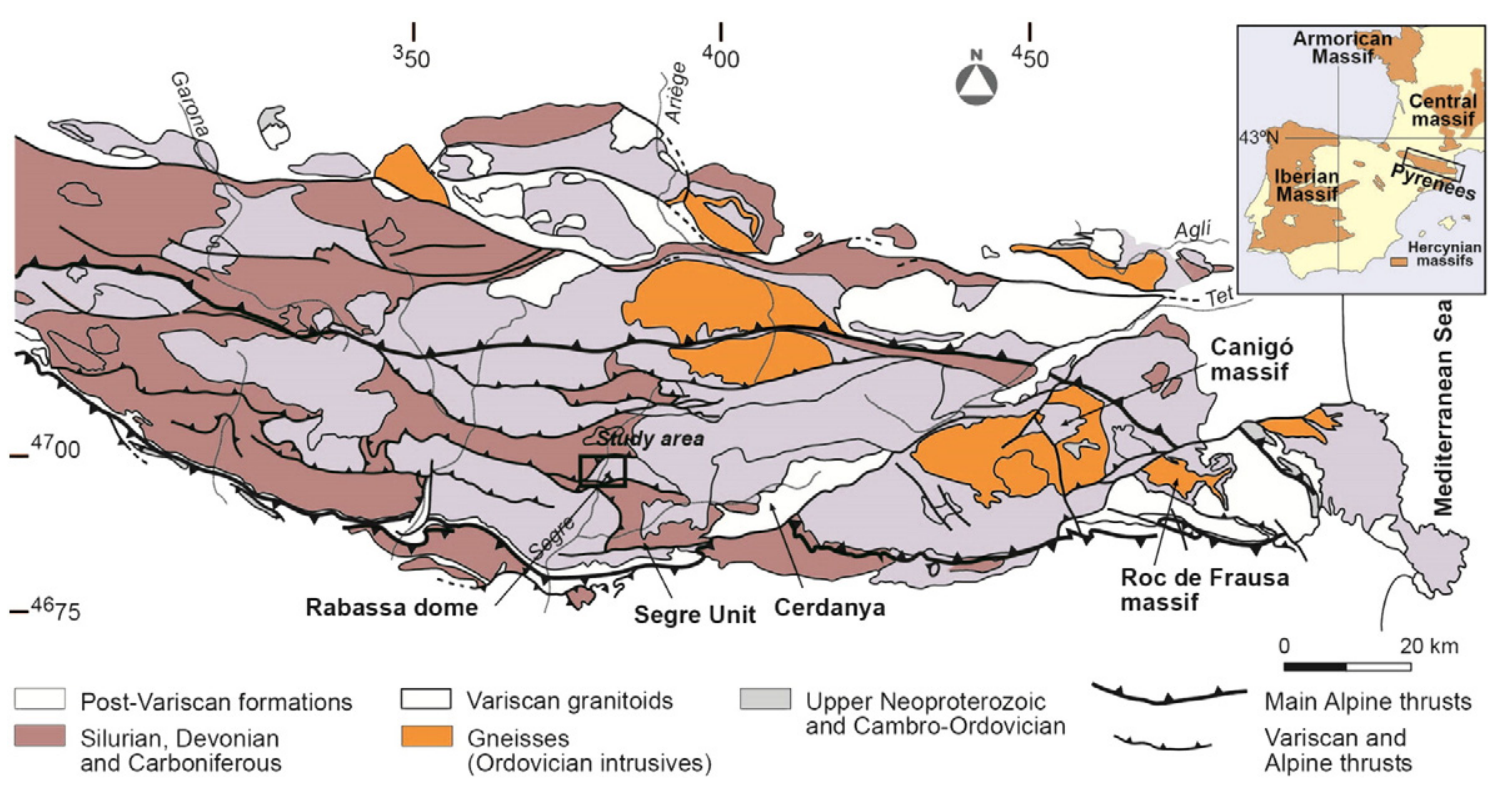

Fig. 1. Simplified geological map of the Central and Eastern Pyrenees showing the location of the study area.

complete view of the paleogeography of the Northern Gondwana margin during the Cambro-Ordovician.

\section{Geological setting}

Pre-Variscan rocks involved in the Alpine thrust sheets crop out extensively along the backbone of the Pyrenees (Fig. 1) forming an E-W elongated strip unconformably overlain by Mesozoic and Cenozoic rocks with no continuity with the neighboring Variscan outcrops (Fig. 1). In the Central and Eastern Pyrenees a complete pre-Variscan succession, ranging in age from late Neoproterozoic to middle Carboniferous, can be identified. The lower part of this succession is a thick azoic metasedimentary sequence covered by the Upper Ordovician unconformity (Fig. 2). Its actual thickness is unknown (3000 m?) since its lower boundary is not exposed. Classically, it has been divided into two parts. Its lower part (1500 m? thick) is lithologically heterogeneous and consists of metapelites and metagreywackes interbedded with numerous layers of marble, quartzite, calc-silicate and orthogneiss sheets (Série de Canaveilles, Cavet, 1957; Canaveilles Group, Laumonier, 1988) (Fig. 2). It includes syn-sedimentary metavolcanic rocks that have yielded late Neoproterozoic-early Cambrian U-Pb ages for this lower part of the sequence ( $575 \pm 4$ Ma in the Canigó massif, $558 \pm 3$ Ma in the Cap de Creus massif, LA-ICP-MS in zircon, Casas et al., 2015). The upper part is a monotonous $1500 \mathrm{~m}$ ? thick rhythmic alternation of very low grade metamorphosed sandstones and shales (Schistes de Jújols, Cavet, 1957; Jújols Group, Laumonier, 1988). In contrast to the lower sequence, no metavolcanic intercalations have been found in this upper part, precluding its precise dating. Furthermore, its almost complete lack of fossil record has sparked off an ongoing debate on which is the actual age of this upper part of the sequence (middle/ late Cambrian, Llopis Lladó, 1965; Abad, 1987; late Cambrian/Early Ordovician, Guitard et al., 1998; middle Cambrian to Early Ordovician, Castiñeiras et al., 2008). The only biostratigraphic datum is a poorly preserved acritarch assemblage that suggests a late Cambrian (Furongian)Early Ordovician age for this upper part of the sequence lying to the east of the study area (Casas and Palacios, 2012).

A well-dated Upper Ordovician succession (based on brachiopods, bryozoans, cystoids, corals, and trilobites, Cavet, 1957; Hartevelt, 1970) lies unconformably over the aforementioned sequence (Santanach, 1972a; García-Sansegundo and Alonso, 1989; Den Brok, 1989; Kriegsman et al., 1989; Casas and Fernández, 2007) (Fig. 2). Although the magnitude of this unconformity is not easy to evaluate, it can be assumed that there was considerable erosion before the Late Ordovician deposition since Upper Ordovician rocks overlie different sections of the pre-Upper Ordovician succession in the Central and Eastern Pyrenees (Santanach, 1972a; Laumonier and Guitard, 1986; Cirés et al., 1994; Muñoz et al., 1994). The Upper Ordovician rocks constitute a finingupwards sequence with marked variations in thickness (100-1000 m) in which Hartevelt (1970) defined five main siliciclastic formations made up of very low grade metamorphosed rocks. In the study area, only four of these formations can be recognized with some lithologic variations all across the different units (Figs. 2 and 3). The Rabassa Conglomerate Formation is made up of red-purple, unfossiliferous conglomerates and sandstones that form discontinuous lenses ranging in thickness from a few meters to $200 \mathrm{~m}$. Slate, quartzite and quartz-vein clasts are subrounded to well-rounded and reach up to $50 \mathrm{~cm}$ in diameter. The Rabassa conglomerates, attributed by Hartevelt (1970) to the Sandbian, are conformably overlain by the Cava Formation that ranges in thickness from 100 to $800 \mathrm{~m}$. Feldspathic sandstones predominate in the lower part of this formation, and are overlain by shales, siltstones and fine-grained sandstones, typically green or purple in color in their upper parts. Brachiopods and bryozoans are locally abundant and allow Gil-Peña et al. (2004) to attribute a Caradoc-Ashgill transition age (Katian) to this formation. The Ansovell Formation consists of monotonous, black and grey slates, with very few sandstone lenses, that in the Rabassa Dome reaches a thickness of $40-50 \mathrm{~m}$. This formation is overlain by the Bar Quartzite Formation, which consists of dark-grey, medium-rounded grained quartzites with ripples in its upper part. An Ashgillian age has been proposed for the Ansovell and Bar formations by Hartevelt (1970), although Sanz-López et al. (2002) suggest that the Ordovician-Silurian boundary can be located within the Bar quartzite, based on the conodont content from carbonate nodules on equivalent lateral sequences. During the Silurian, black shales were deposited, which grade upwards into alternating black limestones and shales. The Devonian is represented by a limestone sequence, whereas the Carboniferous is made up of a detrital sequence (Culm facies) composed of slates with sandstones and conglomerates that overlie unconformably the aforementioned upper Paleozoic sequence.

The Variscan deformation (late Visean to Serpukhovian) accompanied by low- to high-temperature low-pressure metamorphism affected all these sequences (Guitard, 1970; Zwart, 1979; Vilà et al., 2007). Syn- to late-orogenic granitoids (late Bashkirian-Kasimovian, Romer and Soler, 1995; Maurel et al., 2004; Aguilar et al., 2014 and references therein) intruded mainly into the upper levels of the succession. It 


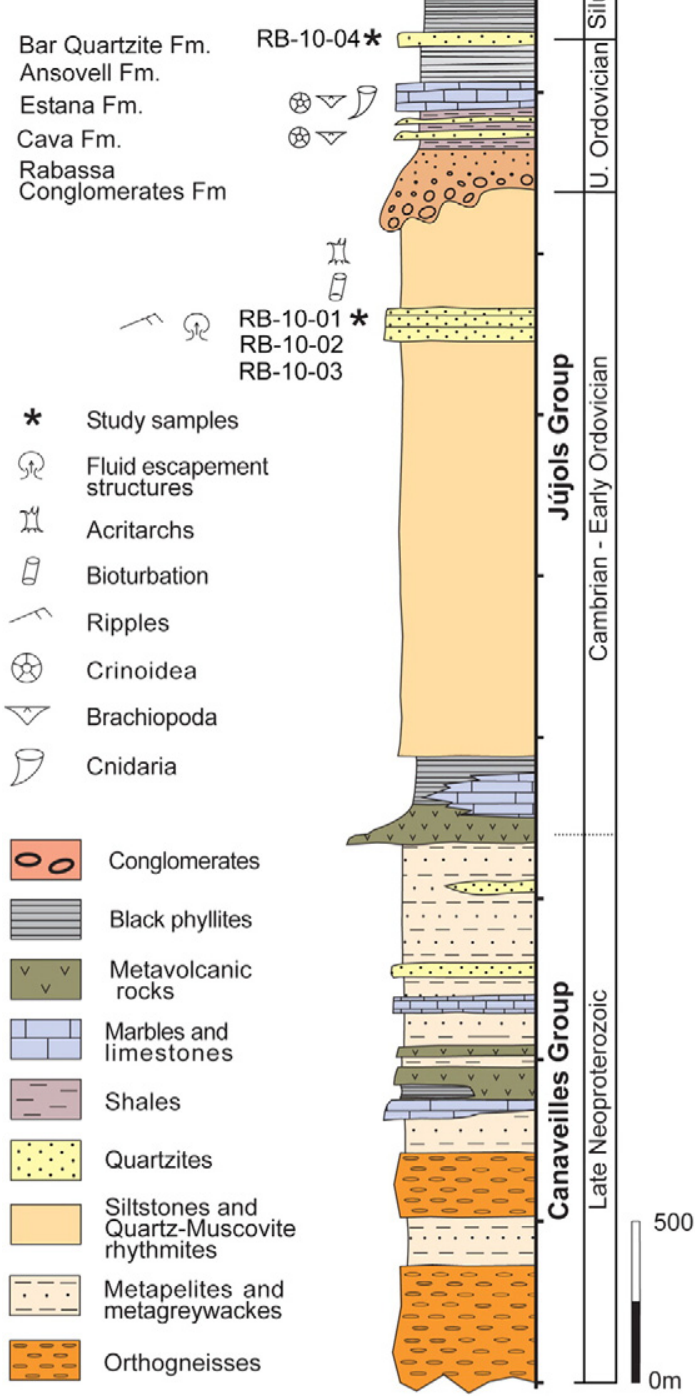

Fig. 2. Synthetic stratigraphic column of the pre-Silurian rocks of the Rabassa dome with the location of the study samples. Stratigraphic data from Ayora and Casas (1986) Guitard (1970) and Santanach (1972b).

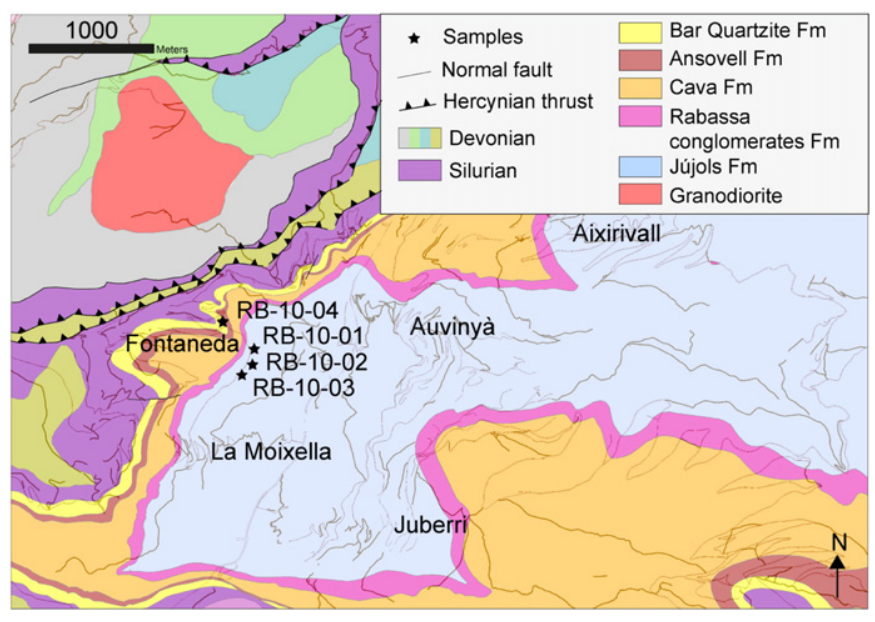

Fig. 3. Geological map of the northern slope of the Rabassa dome with the location of the sites from where study samples were taken. should be noted that in the Pyrenees no tectono-metamorphic events related to the Cadomian orogeny have ever been described and that only a weakly developed Ordovician deformation (Mid? to Late Ordovician in age) has been reported so far (Casas, 2010), which gave rise to folds without cleavage development and normal faults. Finally, the Alpine cycle did not provoke any substantial penetrative deformation in the Variscan basement rocks (Muñoz, 1992).

\section{Sampling rationale}

In order to better constrain the age of the Jújols Group, the time gap involved in the Upper Ordovician unconformity and possible differences in the source areas, we selected three samples of quartzites from just below the unconformity and one sample of quartzite from above it.

Samples RB-10-01, RB-10-02 and RB-10-03 correspond to quartzites from the uppermost part of the Jújols Group collected near the village of La Moixella on the northern slope of the Rabassa Dome (Andorra), below the Upper Ordovician unconformity (Figs. 2 and 3). The Rabassa Dome is the western termination of the Canigó massif and in this area, the Jújols Group consists of a rhythmic alternation of sandstones, siltstones and mudstone layers, $1 \mathrm{~mm}$ to several centimetres thick. Layers range in color from grey to a characteristic light green or light brown. Very fine-grained quartzites up to $1 \mathrm{~m}$ in thickness occur at the top of the succession and exhibit graded bedding, load casts and crossbedding, and the quartz grains are virtually undeformed. Sample RB-1004 corresponds to the Upper Ordovician Bar quartzite and is a mediumgrained, almost pure quartzite with some undeformed chlorite-mica blasts.

\section{Methods}

The zircon concentrate was separated at the Departamento de Petrología y Geoquímica (Universidad Complutense, Madrid). Fresh samples were crushed in a jaw crusher, ground in a disc mill and sieved for the fraction below $250 \mu \mathrm{m}$. The samples were then washed and the heavy minerals concentrated using a Wilfley Table. A Frantz isodynamic separator was used to throw out the magnetic minerals. A final density separation of the non-magnetic fraction was carried out using methylene iodide. An assortment of zircon grains of all sizes and morphological types was obtained by handpicking under a binocular microscope, then mounted in resin blocks and polished to half their thickness. Cathodoluminescence and secondary electron images from the zircons were taken on a JEOL JSM-840 electron microscope housed at the Centres Científics i Tecnològics of the Universitat de Barcelona to identify internal textures, inclusions and fractures.

Zircons were analyzed for $\mathrm{U}$, Th and $\mathrm{Pb}$ isotopes using the LA-ICP-MS technique at the Museum für Mineralogie und Geologie (Senckenberg Naturhistorische Sammlungen Dresden) with a Thermo-Scientific Element 2 XR sector field ICP-MS coupled to a New Wave UP-193 Excimer Laser System. A teardrop-shaped, low-volume laser cell by Ben Jähne (Dresden, Germany) permitted the sequential sampling of heterogeneous grains (e.g., growth zones) during time-resolved data acquisition. Each analysis consisted of approximately $15 \mathrm{~s}$ background acquisition followed by $35 \mathrm{~s}$ data acquisition, using a laser spot-size of 25 and $35 \mu \mathrm{m}$, respectively. A common- $\mathrm{Pb}$ correction based on the interference- and background-corrected 204Pb signal and a model $\mathrm{Pb}$ composition (Stacey and Kramers, 1975) was carried out if necessary. The necessity of the correction is judged on whether the corrected $207 \mathrm{~Pb} / 206 \mathrm{~Pb}$ lies outside of the internal errors of the measured ratios. Raw data were corrected for background signal, common Pb, laserinduced elemental fractionation, instrumental mass discrimination and time-dependant elemental fractionation of $\mathrm{Pb} / \mathrm{Th}$ and $\mathrm{Pb} / \mathrm{U}$ using an Excel ${ }^{\circledR}$ spread sheet program developed by Axel Gerdes (Institute of Geosciences, Johann Wolfgang Goethe-University Frankfurt, Frankfurt am Main, Germany). Reported uncertainties were propagated by quadratic addition of the external reproducibility obtained from the 
standard zircon GJ-1 ( 0.6\% and $0.5-1 \%$ for the $207 \mathrm{~Pb} / 206 \mathrm{~Pb}$ and $206 \mathrm{~Pb} / 238 \mathrm{U}$, respectively) during individual analytical sessions and the within-run precision of each analysis. Concordia diagrams ( $2 \sigma$ error ellipses) and concordia ages (95\% confidence level) were produced using Isoplot/Ex 2.49 (Ludwig, 2001) and frequency and relative probability plots using AgeDisplay (Sircombe, 2004). The 207Pb/206Pb age was taken for interpretation for all zircons $>1.0 \mathrm{Ga}$, and the $206 \mathrm{~Pb} /$ $238 \mathrm{U}$ ages for younger grains. For further details of the analytical protocol and data processing, see Frei and Gerdes (2009).

\section{Results}

The results of the $\mathrm{U}-\mathrm{Pb}$ dating of the detrital zircon are given in Tables A-1-A-4 (available as an electronic supplement from the journal's website). Concordia diagrams are shown in Fig. 4 and relative probability plots in Fig. 5 . The errors reported in the text are $2 \sigma$. All stratigraphic terms correspond to the 2015/01 version of the timescale of the International Commission on Stratigraphy.

\subsection{Sample RB-10-01 (Cambro-Ordovician quartzite from the Jújols Group)}

One hundred and thirty analyses were carried out in 126 detrital zircon grains, of which 104 were concordant (in a range of concordance of $90-110 \%$ ). The ages vary between $\sim 450$ and 3360 Ma. Most of the analyses (59\%) yielded a Neoproterozoic age, with two main peaks at around 690 and $990 \mathrm{Ma}$ (Fig. 5). Two grains yielded Paleozoic ages: one is Late Cambrian ( $489 \pm 10 \mathrm{Ma}$ ) and the other is Early Ordovician $(479 \pm 9 \mathrm{Ma})$. A total of $14 \%$ of the grains yielded Stenian ages, ranging from 1000 to 1163 Ma. A 17\% of Paleoproterozoic ages range from 1844 to $2454 \mathrm{Ma}$. Only $8 \%$ of the analyses were Archean in age, with one isolated zircon providing a Paleoarchean age (3359 $\pm 16 \mathrm{Ma})$.

\subsection{Sample RB-10 02 (Cambro-Ordovician quartzite from the Jújols Group)}

Ninety analyses were performed in as much detrital zircon grains, of which 73 were concordant. Ages range from $~ 500$ to $2600 \mathrm{Ma}$. An overwhelming $70 \%$ of the zircon population yielded a Neoproterozoic age, ranging from 549 to $995 \mathrm{Ma}$, with an acme at around $618 \mathrm{Ma}$. These Neoproterozoic zircon grains are mostly from the Ediacaran (30\%) and Tonian (25\%) periods (Fig. 5). Only one zircon yielded a Cambrian age, specifically $502 \pm 9$ Ma. Three zircon grains yielded a Stenian age, ranging from 1030 to $1071 \mathrm{Ma}$, and two zircon grains yield other Mesoproterozoic ages (1389 \pm 34 and $1526 \pm 14 \mathrm{Ma})$. A total of $15 \%$ of the grains were Paleoproterozoic, ranging in age from 1833 to $2483 \mathrm{Ma}$; finally, $7 \%$ of the population yielded Archean ages.

\subsection{Sample RB-10-03 (Cambro-Ordovician quartzite from the Jújols Group)}

One hundred and fifty detrital zircon grains were analyzed, resulting in 115 concordant analyses. The ages range from 475 to 2660 Ma. Most

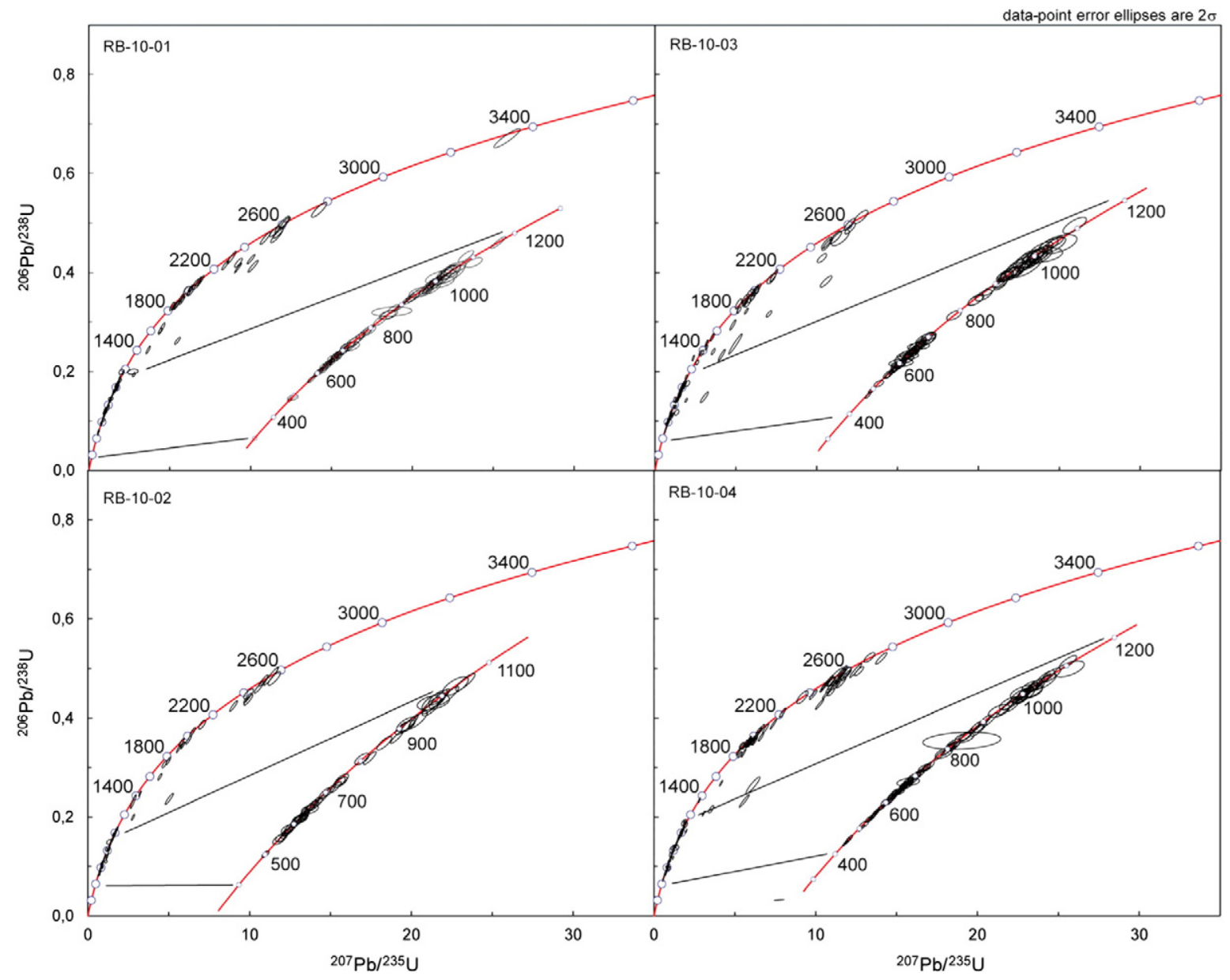

Fig. 4. Concordia diagrams for samples RB-10-01, RB-10-02, RB-10-03 and RB-10-04. Ellipses represent 2 $\sigma$ uncertainties. 


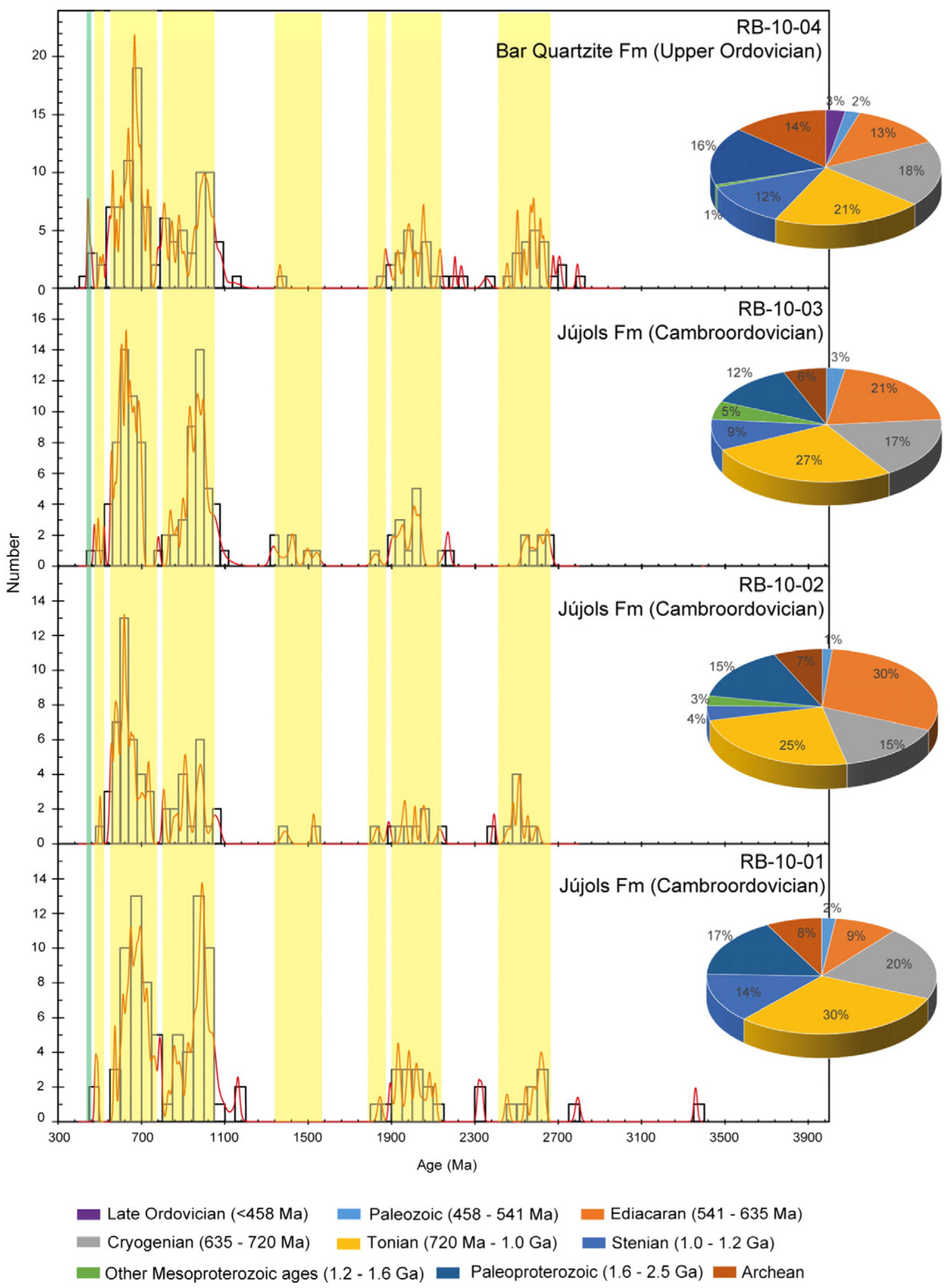

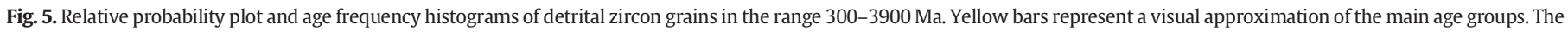

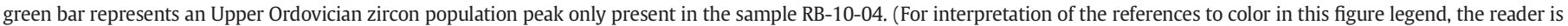
referred to the web version of this article.)

of the analyses (72\%) yielded Neoproterozoic ages, with two main peaks at around 605 and $996 \mathrm{Ma}$. Three grains yielded a Paleozoic age, one Early Ordovician (475 $\pm 10 \mathrm{Ma}$ ) and two Cambrian (493 $\pm 9 \mathrm{Ma}$ and $520 \pm 11 \mathrm{Ma})$. A total of $10 \%$ of the grains yielded a Stenian age, ranging from 1000 to $1083 \mathrm{Ma}$, while 6\% have other Mesoproterozoic ages (between 1331 and $1541 \mathrm{Ma}$ ). Finally, 14\% of the total population yielded a Paleoproterozoic age ranging from 1824 to $2171 \mathrm{Ma}$, while $7 \%$ of the analyses were Archean in age. 
5.4. Sample RB-10-04 (Upper Ordovician quartzite from the Bar Quartzite Formation)

One hundred and seventy analyses were made in 164 detrital zircon grains, of which 147 were concordant. The ages range from 440 to $\sim 2790 \mathrm{Ma}$. A total of $52 \%$ of all zircons in the sample yielded a Neoproterozoic age, ranging from 548 to $995 \mathrm{Ma}$, with a main peak at $\sim 667 \mathrm{Ma}$ and a second peak at $\sim 810 \mathrm{Ma}$. Four of the zircon grains yielded Late Ordovician ages, the youngest being $442 \pm 9 \mathrm{Ma}$; three Cambrian analyses range in age from $\sim 500$ to $\sim 540 \mathrm{Ma}$. The Stenian age represents $12 \%$ of the zircon grains; only one grain yielded a different Mesoproterozoic age ( $1365 \pm 14 \mathrm{Ma})$. Paleoproterozoic ages represent a $16 \%$ of the dataset and range from 1870 to $2455 \mathrm{Ma}$. Archean ages were obtained in the $14 \%$ of the grains, ranging from 2500 to 1792 Ma. No Middle nor Early Ordovician ages were obtained.

\section{Interpretation}

\subsection{Maximum depositional age}

One of the goals of this work is to determine the maximum depositional age of the uppermost part of the Jújols Group in order to (1) settle the Cambrian or Ordovician age attributed to this sequence and (2) confirm the presence and the significance of the intraOrdovician unconformity.

For the Jújols Group, below the unconformity, the youngest detrital zircons obtained in the pre-Upper Ordovician samples (RB-10-01, RB10-02 and RB-10-03) span from 448 to $493 \mathrm{Ma}$. Two grains from sample RB-10-01 yield a Late Ordovician age, which is in direct conflict with the existence of an important unconformity between the Jújols Group and the Upper Ordovician sequence. Furthermore, one of the analyses (b18) was performed in a rim of uncertain origin that partially overprints a magmatic core. The irregular boundary between both areas, together with the diffuse zoning of the rim, suggest that this zircon experienced a recrystallization process that could have resulted in a slight lead loss, which is difficult to assess in laser ablation $\mathrm{U}-\mathrm{Pb}$ data. Getting rid of these two Late Ordovician ages, the remaining data are distributed between Early Ordovician (ca. 475 and ca. $479 \mathrm{Ma}$ ) and late Cambrian (ca. 489 and ca. $493 \mathrm{Ma}$ ). Even though it is not possible to come up with a precise maximum sedimentation age, these data uphold the presumed Early Ordovician age of the top of this sequence (around $475 \mathrm{Ma}$ ) and they suggest that the late Cambrian could be present in this sequence.

Regarding the Bar Quartzite Fm., above the unconformity, the presence in sample RB-10-04 of only two zircons of 442 and 443 Ma also precludes obtaining a precise maximum sedimentation age. However, these ages suggest that the Late Ordovician-Llandovery boundary could be included in the Bar Quartzite Fm.

\subsection{Main age populations}

The Age Pick program (Gehrels, 2012) was used to define statistically robust, mutually comparable age populations that can also be juxtaposed with samples from other peri-Gondwanan regions. The results are shown in Fig. 6, and Table 1 is a summary of the most important age populations, as well as the youngest and oldest zircons, extracted from the analysis with the Age Pick program.

In order of abundance, and taking into account jointly the results from the analyses of all four samples, the main age groups population of the samples from Andorra are as follows: (1) The main age population is Neoproterozoic, in the range 770-550 Ma (yellow bar), (2) the second age population is in the range 1100-770 Ma (Tonian-Stenian, blue bar) which has previously been reported in the literature as a Grenvillian-age population, (3) finally, both Neoarchean (ca. 2650-2500 Ma, green bar) and Orosirian (ca. 2075-1900 Ma, red bar) populations are present in a similar proportion. The youngest population corresponds to early Cambrian-Early Ordovician zircons (ca. 470-520 Ma) in samples RB-10-01, RB-10-02 and RB-10-03, whereas sample RB-10-04 presents an early Silurian-Late Ordovician age population (ca. $440-455 \mathrm{Ma}$ ).

\subsection{The Upper Ordovician unconformity}

The Upper Ordovician angular unconformity in the Pyrenees has been described by Santanach (1972a) and García-Sansegundo and Alonso (1989) in the southern slope of the Canigó massif and in the Garona dome. These authors attributed the angular unconformity to basement tilting and subsequent erosion owing to a Late Ordovician fracture episode. According to Santanach (1972a), tilting caused different attitudes of the bedding planes in both the Upper Ordovician and the underlying Cambro-Ordovician series that, and in turn, gave rise to a different arrangement of the Variscan minor structures in both sequences. On the other hand, Casas (2010) and Casas et al. (2012) suggested that the unconformity was linked to a Middle Ordovician (?) system of folds that affected the pre-Upper Ordovician materials and are not developed in the Upper Ordovician materials. These folds can account for the deformation and uplift of the pre-Upper Ordovician sequence and, together with an important erosional event, could have originated the Upper Ordovician unconformity. On the other hand, cartographic data shows that Upper Ordovician rocks lie on different terms of the pre-Upper Ordovician sequence all along the Pyrenees (Santanach, 1972a; Laumonier and Guitard, 1986; Cirés et al., 1994; Muñoz et al., 1994). In the La Molina area, in the southern slope op the Canigó massif, the Upper Ordovician rocks lie on the uppermost terms of the pre-Upper Ordovician sequence, that is, the upper part of the Jújols Group (Muñoz et al., 1994). In this area an acritarch assemblage attributed a late Cambrian (Furongian)-Early Ordovician age for this uppermost part of the Jújols Group (Casas and Palacios, 2012), and suggest that Lower and Middle Ordovician sediments were absent before deposition of the Upper Ordovician succession. This is in accordance with the Early Ordovician maximum depositional age, around $475 \mathrm{Ma}$, obtained in this study for the uppermost part of the Jújols Group and with the absence of Middle Ordovician zircons observed in the study samples. All these facts suggest that Middle Ordovician sediments were probably not deposited in the Pyrenees.

The lack of biostratigraphic data makes it difficult to establish the age of the rest of the Jújols Group. Using lithostratigraphic correlations criteria, J. Álvaro (pers. comm.) suggests that the discontinuous limestone level at the basis of the Jújols Group could be equivalent to the Lastours limestones in the Montagne Noire, late Early Cambrian in age (Álvaro et al., 2014). If this proposal were confirmed, the Jújols Group would comprise the middle and late Cambrian and the lowermost part of the Early Ordovician. The late Neoproterozoic-Cambrian boundary should be located on top of the uppermost volcanic level of the Canaveilles Group.

From our data, the time gap for the Upper Ordovician unconformity is around 30 million years. This gap should be regarded as a maximum one, since the Bar Quartzite Fm. constitutes the uppermost part of the Upper Ordovician succession. In neighboring areas, in the Ribes de Freser area, Upper Ordovician volcanic rocks located just above the unconformity yielded ca. $455 \mathrm{Ma}$ (Martí et al., 2014), and in the Catalan Coastal Ranges, Navidad et al. (2010) obtained the same age, $455 \pm$ $2 \mathrm{Ma}$, for volcanic rocks overlying the basal Upper Ordovician conglomerates. These data reduce the time gap of the unconformity to $\sim 20$ million years. This time gap is similar to that found in the SW of Sardinia ( $\sim 18$ million years) in the classical zone where the Sardic unconformity was described, where well dated Upper Ordovician metasediments overlie late Tremadoc-early Floian (?) sequences (Barca et al., 1987; Pillola et al., 2008).

The similarity displayed by the age populations of the samples both above and below the unconformity suggests that neither the 
RB-10-01

\begin{tabular}{|c|c|c|c|c|}
\hline \multicolumn{5}{|c|}{ DZ AGES } \\
\hline MIN AGE & MAX AGE & \# GRAINS & $\begin{array}{c}\text { PEAK } \\
\text { AGE }\end{array}$ & \# GRAINS \\
\hline 600 & 769 & 33 & 613 & 4 \\
\hline 772 & 800 & 3 & 650 & 6 \\
\hline 841 & 849 & 0 & 690 & 7 \\
\hline 854 & 873 & 3 & 723 & 6 \\
\hline 878 & 886 & 1 & 758 & 3 \\
\hline 906 & 910 & 0 & 789 & 3 \\
\hline 915 & 1107 & 28 & 859 & 3 \\
\hline 1111 & 1114 & 0 & 881 & 3 \\
\hline 1925 & 1946 & 2 & 925 & 5 \\
\hline 1973 & 2001 & 2 & 991 & 16 \\
\hline 2015 & 2032 & 1 & 1035 & 9 \\
\hline 2037 & 2041 & 0 & 1931 & 4 \\
\hline 2067 & 2075 & 1 & 1984 & 3 \\
\hline 2093 & 2099 & 0 & 2019 & 3 \\
\hline 2606 & 2630 & 2 & 2619 & 4 \\
\hline
\end{tabular}

$\underline{\text { RB-10-03 }}$

\begin{tabular}{|c|c|c|c|c|}
\hline \multicolumn{5}{|c|}{ DZ AGES } \\
\hline MIN AGE & MAX AGE & \# GRAINS & $\begin{array}{c}\text { PEAK } \\
\text { AGE }\end{array}$ & \# GRAINS \\
\hline 547 & 568 & 3 & 556 & 3 \\
\hline 571 & 710 & 41 & 575 & 5 \\
\hline 839 & 852 & 1 & 605 & 10 \\
\hline 890 & 1109 & 36 & 626 & 9 \\
\hline 1910 & 2051 & 10 & 646 & 8 \\
\hline 2592 & 2604 & 0 & 666 & 8 \\
\hline 2623 & 2667 & 2 & 685 & 8 \\
\hline & & & 840 & 3 \\
\hline & & & 900 & 3 \\
\hline & & & 933 & 10 \\
\hline & & & 971 & 13 \\
\hline & & & 996 & 15 \\
\hline & & & 1953 & 3 \\
\hline & & & 2009 & 5 \\
\hline & & & 2029 & 5 \\
\hline & & & 2647 & 3 \\
\hline
\end{tabular}

RB-10-02

\begin{tabular}{|c|c|c|c|c|}
\hline \multicolumn{5}{|c|}{ DZ AGES } \\
\hline MIN AGE & MAX AGE & \# GRAINS & $\begin{array}{c}\text { PEAK } \\
\text { AGE }\end{array}$ & \# GRAINS \\
\hline 544 & 683 & 29 & 556 & 4 \\
\hline 690 & 698 & 1 & 576 & 6 \\
\hline 703 & 713 & 1 & 618 & 9 \\
\hline 718 & 746 & 3 & 652 & 5 \\
\hline 894 & 932 & 5 & 660 & 5 \\
\hline 961 & 1013 & 6 & 705 & 3 \\
\hline 1045 & 1073 & 2 & 734 & 3 \\
\hline 2503 & 2522 & 3 & 910 & 5 \\
\hline & & & 983 & 6 \\
\hline & & & 1053 & 3 \\
\hline & & & 2513 & 3 \\
\hline
\end{tabular}

RB-10-04

\begin{tabular}{|c|c|c|c|c|}
\hline \multicolumn{5}{|c|}{ DZ AGES } \\
\hline MIN AGE & MAX AGE & \# GRAINS & $\begin{array}{c}\text { PEAK } \\
\text { AGE }\end{array}$ & \# GRAINS \\
\hline 441 & 451 & 3 & 443 & 3 \\
\hline 536 & 575 & 7 & 549 & 4 \\
\hline 583 & 741 & 42 & 563 & 5 \\
\hline 780 & 899 & 14 & 601 & 4 \\
\hline 927 & 1112 & 27 & 637 & 7 \\
\hline 1865 & 1881 & 2 & 667 & 13 \\
\hline 1940 & 1944 & 0 & 692 & 10 \\
\hline 1963 & 2001 & 4 & 731 & 4 \\
\hline 2036 & 2064 & 5 & 781 & 3 \\
\hline 2497 & 2510 & 3 & 810 & 6 \\
\hline 2554 & 2593 & 6 & 846 & 4 \\
\hline 2603 & 2629 & 4 & 880 & 4 \\
\hline & & & 960 & 5 \\
\hline & & & 1002 & 14 \\
\hline & & & 1870 & 3 \\
\hline & & & 1983 & 4 \\
\hline & & & 2053 & 5 \\
\hline & & & 2505 & 3 \\
\hline & & & 2568 & 5 \\
\hline & & & 2582 & 5 \\
\hline & & & 2614 & 3 \\
\hline & & & 2628 & 3 \\
\hline
\end{tabular}

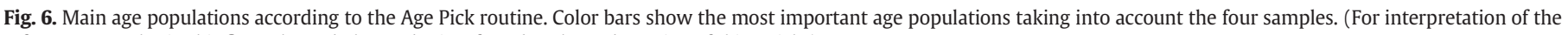
references to color in this figure legend, the reader is referred to the web version of this article.)

depositional system nor the source area changed substantially during the time span represented by the unconformity (i.e., Middle Ordovician).

\subsection{Limitations of the detrital zircon data}

It is noteworthy that in our case, and despite the large number of analyzed data, the obtained Paleozoic ages in the overall samples are very scarce. This fact is in contrast with the existence of large Neoproterozoic and Mesoproterozic zircon age populations. As a result, the obtained data provide solid information that allows us to discuss wide regional aspects, as provenance areas or the paleoposition of the study sequences; nevertheless, these data are insufficient to precise local aspects of the study sequences, as their maximum depositional age. This limitation is implied in other detrital zircon age studies, in which the paucity of youngest data is also noticeable (e.g., Pereira et al., 2012a; Shaw et al., 2014). Moreover, this can be stressed if some of the obtained ages are too young, and are in conflict with regional or stratigraphic evidences.

\section{Comparison with other Perigondwanan terranes and paleogeographic implications}

Just at the beginning of the surge experienced by detrital zircon studies in the European Variscan massifs, Friedl et al. (2000) pointed out a significant disparity in the detrital zircon signatures obtained in these massifs, i.e. the presence or lack of Mesoproterozoic ages. In their interpretation, a population of Mesoproterozoic zircons was indicative of a South American provenance (represented in Europe by the Avalonian terrane), whereas its absence was distinctive of a West African derivation (represented by the Armorican Massif, Friedl et al., 2000).

The finding of Mesoproterozoic ages in detrital zircon populations from Proterozoic-early Paleozoic rocks from NW Iberia (FernándezSuárez et al., 1999) led some authors to place Iberia at the westernmost edge of the Gondwana margin, close to the Mesoproterozoic source area; whereas other European Variscan massifs, lacking the Mesoproterozoic signature, were set to the east, in front of the West African Craton (e.g., see reconstructions by Fernández-Suárez et al., 2000; Linnemann et al., 2008).

Table 1

Summary of the main age population groups for each sample, as well as the youngest and oldest zircons and youngest age populations identified using the Age Pick routine.

\begin{tabular}{|c|c|c|c|c|}
\hline & RB-10-01 & RB-10-02 & RB-10-03 & RB-10-04 \\
\hline Main age group & $600-800(690)$ & $544-746(618)$ & $547-710(605)$ & $536-741(667)$ \\
\hline 2nd age group & $906-1114(991)$ & 894-1073 (983) & 890-1109 (996) & $927-1112(1002)$ \\
\hline 3rd AGE GROUP & 1925-2099 (1931) & $2503-2522(2513)$ & 1910-2051 (2009) & $2497-2629(2582)$ \\
\hline Youngest zircon & $479 \pm 9(100 \%)$ & $502 \pm 9(100 \%)$ & $475 \pm 10(95 \%)$ & $442 \pm 9(100 \%)$ \\
\hline Youngest age population & 613 & 556 & 556 & 443 \\
\hline Oldest zircon & $3359 \pm 16(99 \%)$ & $2599 \pm 24(97 \%)$ & $2656 \pm 30(100 \%)$ & $2792 \pm 14(97 \%)$ \\
\hline
\end{tabular}


However, these reconstructions were in conflict with paleontological evidence exposed by Gutiérrez Marco et al. (2002), who found Ordovician benthic faunas in Iberia similar to those found in the Algerian Sahara. Later on, geochronological studies in the Saharan Craton and in the Arabian-Nubian Shield identified an additional source for the Mesoproterozoic zircons (see Avigad et al., 2012, and references therein).

At present, the most accepted paleogeographic reconstructions of the northern Gondwana margin during the late Proterozoic-early Paleozoic place the terranes either to the west, in front of the West African Craton, if no Mesoproterozoic ages are found, or to the east, next to the Sahara Metacraton and the Arabian-Nubian Shield, if the Mesoproterozoic signature is maximum (e.g., Meinhold et al., 2013).

Following this criterion, the North Armorica Domain, the uppermost allochthonous terrane in NW Iberia (Fernández-Suárez et al., 2002, 2003; Martínez Catalán et al., 2004), the Ossa Morena (Pereira et al., 2011, 2012b) and the Saxothuringian zones (Linnemann et al., 2008) would occupy the westernmost position, as their Neoproterozoic and early Paleozoic rocks lack Mesoproterozoic zircons. In sharp contrast, Talavera et al. (2012, 2015) and Orejana et al. (2015) suggest a paleoposition close to the Sahara Metacraton and the Arabian-Nubian Shield for the autochthonous sequences of the Central Iberian Zone. Likewise, Avigad et al. (2012) propose a similar paleoposition for Sardinia, on the basis of the detrital signal of quartz-arenites from the lower and middle Cambrian of SW Sardinia that bear a noticeable Grenvillian (1.0-1.1 Ga) zircon population. Similar conclusions have been reached by Williams et al. (2012) that proposes an East African origin for Sicily based on the presence of Grenvillian-aged detrital/ inherited zircons, and on the scarcity of zircon in the age range 2.2-1.9 Ga, in the basement of the Peloritani Mountains. Finally, the Basal allochthonous Units and the parautochthonous complexes of NW Iberia (Díez-Fernández et al., 2010, 2012) would be located in an intermediate position, between the West African Craton and the Sahara
Metacraton, due to the minor relative proportions of Mesoproterozoic zircons compared to those of the NW Iberian autochthon.

Concerning the Pyrenees, the presence of the Grenvillian age population in the Andorra samples, suggests that their paleoposition was close to the eastern North Africa domain during the Early Paleozoic. In order to precise this hypothesis, we have compared our data with the available detrital zircon data from the nearest Perigondwanan terranes: Sardinia, Sicily and the Iberian Massif (Fig. 7). The samples chosen were: 1) samples S-5 and S-14 from Sardinia (Avigad et al., 2012); 2) sample FIU-07 form Sicily (Williams et al., 2012) and 3) samples GCH-PA-5, OD-3 and IBR-2 from the Iberian Massif (Díez-Fernández et al., 2012; Fernández-Suárez et al., 2014; Shaw et al., 2014 respectively). We have overlaid the markers derived from the main age populations from the Pyrenees on the relative probability plots of these samples (Fig. 8), which enabled us to compare the Pyrenean populations with these other Perigondwanan samples.

Sardinian S-5 and S-14 samples are from early-middle Cambrian quartz-arenites and exhibit Neoproterozoic zircon populations in similar proportions to Andorran samples (Fig. 8). Sample S-5 has a small Mesoproterozoic zircon population than sample S-14, similar to samples RB-10-02, RB-10-03 and RB-10-04 (Fig. 8). The Paleoproterozoic population from sample $\mathrm{S}-14$ is also similar to our four samples, while the Paleoproterozoic population from sample S-5 is considerably poorer. The Neoarchean population is similar to our samples. Sample S-5 yielded small populations at ca. 2100-2300 Ma that are also present in our samples. We can thus conclude that the Sardinian and the Pyrenean detrital zircon populations are very similar and so they could share common source areas and could be located in a close paleoposition during Cambro-Ordovician times.

The Sicilian sample FIU-07 (upper Ediacaran-lower Cambrian paragneiss, Williams et al., 2012) has a younger early Cambrian population. This population is similar to the early Cambrian population described in Andorra despite the fact that the maximum peak in FIU-07

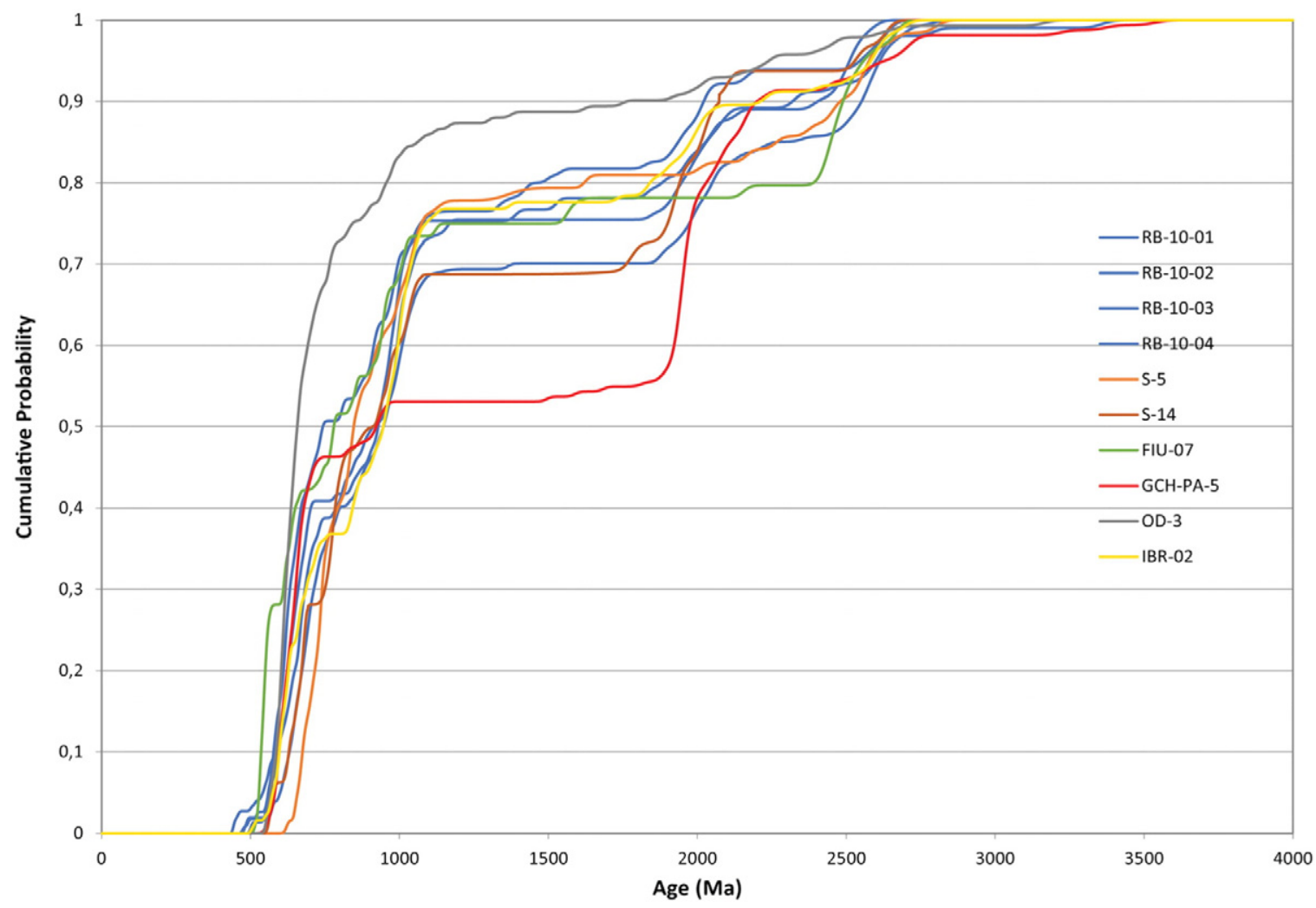

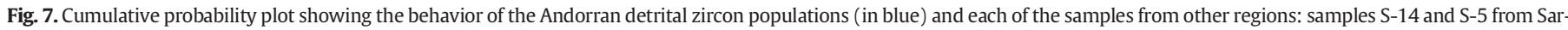

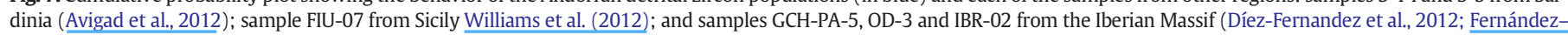
Suárez et al., 2014; Shaw et al., 2014 respectively). (For interpretation of the references to color in this figure legend, the reader is referred to the web version of this article.) 

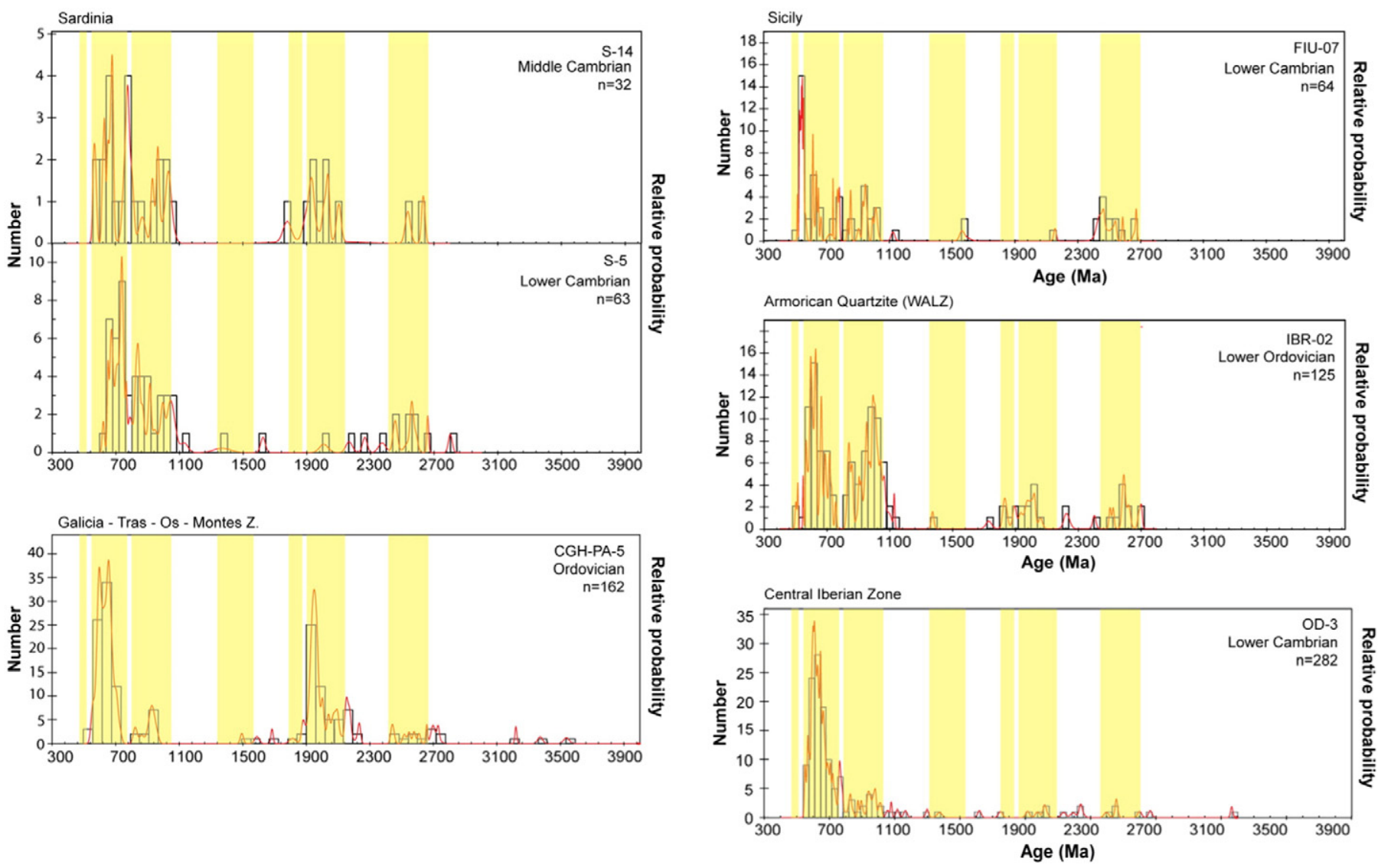

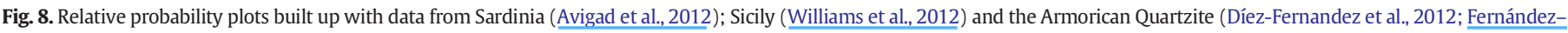

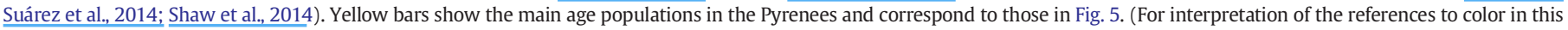
figure legend, the reader is referred to the web version of this article.)

occurred at over $540 \mathrm{Ma}$ and in the Andorran population at around $650 \mathrm{Ma}$ (Fig. 8). Nevertheless, these samples have common zircon populations originated in the Neoproterozoic, as well as a less significant population in the Tonian-Stenian and an older one in the Neoarchean, although the Paleoproterozoic population is missing in the Sicilian sample in a similar way than in the sample S-5 from Sardinia. Thus, sample FIU-07 from Sicily shows a similar population pattern to the Andorran samples except for the lack of a Paleoproterozoic zircon population.

Regarding the Iberian Massif, sample GCH-PA-5 is a quartzite form the Parautochthon or Schistose Domain, (Díez-Fernandez et al., 2012); sample OD-3 is a lower Cambrian sandstone from the Central Iberian Zone (Fernández-Suárez et al., 2014) and sample IBR-02 belongs to the easternmost outcrops of the Lower Ordovician Armorican Quartzite (Shaw et al., 2014). A qualitative visual approach from cumulative probability plots allows us to propose that the detrital zircon populations from samples GCH-PA-5 and OD-3 differ from Andorran populations (Figs. 7 and 8). It should be noted the minor amount of Mesopoterozoic zircons together with a marked Paleoproterozoic population in sample GCH-PA-5. In turn, and in contrast with the Andorran samples, sample OD-3 exhibit reduced Grenvillian, Paleoproterozoic and Archean populations (Fig. 8). On the other hand, Armorican Quartzite sample IBR-02 has a Cambro-Ordovician zircon population that is similar to that observed in samples from Andorra. Neoproterozoic, Tonian-Stenian and Neoarchean populations are also similar to the samples from Andorra. In the Armorican Quartzite sample, Paleoproterozoic population has greater time span than in the Andorran samples. Thus, we suggest that Andorra and the easternmost part of the Iberian Armorican Quartzite may share part of the detrital zircon input and some source areas.

The similarity with the Sardinian age distribution points out that the Andorran samples could have the same source area than the SW of
Sardinia at Ordovician times, somewhere between Libya and Algeria in the west, and the mouth of the Arabian-Nubian drainage system in the east, as shown in Fig. 9. This assumption could be confirmed by the presence of a Late Ordovician zircon population (sample RB-1004) that is coincident with the Late Ordovician zircon population of the Kufra basin in Libya (Meinhold et al., 2013, Fig. 3).

\section{9. Conclusions}

LA-ICP-MS U-Pb detrital zircon analysis of the Jújols Group suggest an Early Ordovician (around $475 \mathrm{Ma}$ ) maximum depositional age for its uppermost part. Combining this data with other published geochronological data, a time gap of $\sim 20$ million years for the Upper Ordovician unconformity in the Pyrenees can be proposed, similar to that of the Sardic unconformity in Sardinia. The absence of a Middle Ordovician age population may be due to a lack of sedimentation at that time, although the similar age pattern on both sides of the unconformity, suggests that neither the depositional system nor the source area changed substantially during the time span represented by this unconformity (Middle Ordovician).

Concerning Bar Quartzite Fm., the presence of only two zircons with ages ca. 442 and ca. 443 Ma precludes obtaining a precise maximum depositional age. However, these data suggest that the Late OrdovicianLlandovery boundary could be included in the Bar Quartzite.

All the study samples analyzed below and above the unconformity show similar $\mathrm{U}-\mathrm{Pb}$ age patterns. The main age populations correspond to Neoproterozoic (Ediacarian-Cryogenian, ca. 550-750 Ma), Grenvillian (Tonian-Stenian, ca. 850-1100 Ma), Paleoproterozoic (Orosirian, ca.1900-2100 Ma) and Neoarchean (ca. 2500-2650 Ma). The paucity of the Cambrian and Ordovician zircon ages in the study 


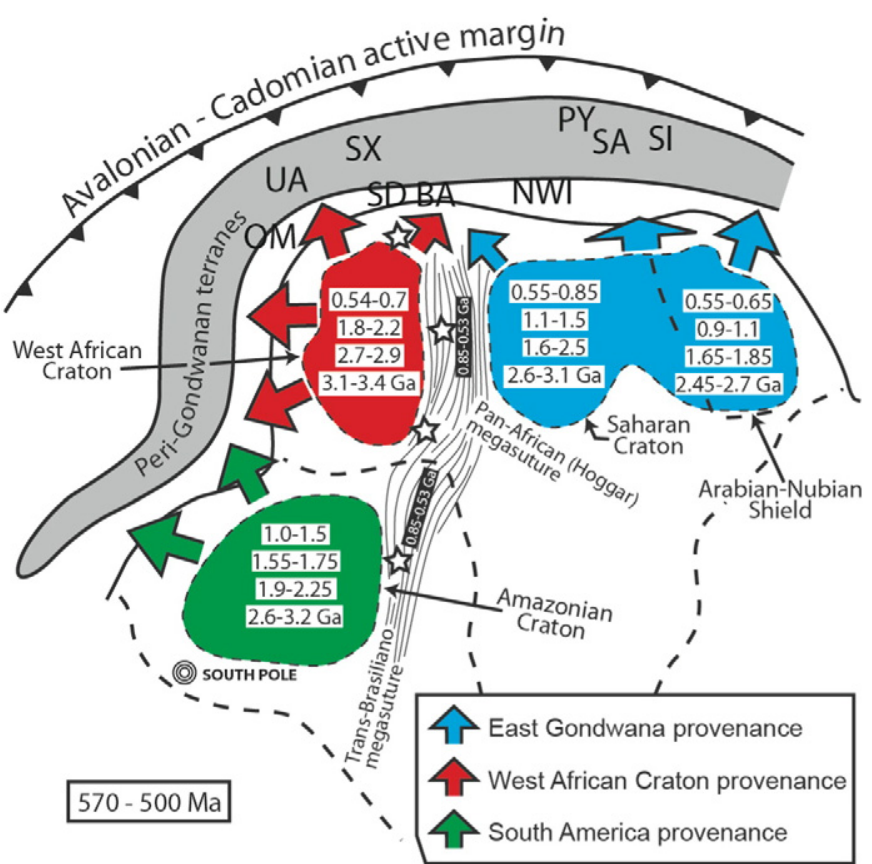

Occurrence of Mesoproterozoic zircon grains in the Gondwana interior

Fig. 9. Simplified reconstruction of Western Gondwana during the late Neoproterozoicearly Paleozoic, modified after Díez-Fernández et al. (2010). Suggested paleoposition of the uppermost terrane of the allochthonous complexes of NW Iberia (UA), the Basal Units of the allochtonus complexes (BA) and the Schistose Donain (SD) after DíezFernández et al. (2010); Ossa-Morena Zone (OM), after Fernández-Suárez et al. (2002), Linnemann et al. (2008) and Pereira et al. (2012a); Saxo-Thuringian Zone (SX) after Linnemann et al. (2008) and Meinhold et al. (2013); Central Iberian, West Asturian and Cantabrian Zones of NW Iberia (NWI) after Fernández-Suárez et al. (2014); Sardinia (SA) after Avigad et al. (2012); Sicily (SI) after Williams et al. (2012) and the Pyrenees (PY) this study.

samples should be stressed, in contrast with the large Neoproterozoic and Mesoproterozic zircon age populations.

The similarity displayed between our samples and the Sardinian zircon age populations suggests that they could share source areas and therefore they also could be located very close to each other in Ordovician times. Based on a comparison with other parts of the northern Gondwana margin, we propose that the Eastern Pyrenees were located in front of the Saharan Metacraton, slightly to the east at the mouth of the Gondwana super-fan system.

Supplementary data to this article can be found online at http://dx. doi.org/10.1016/j.tecto.2016.03.015.

\section{Acknowledgments}

With this contribution to the C. Quesada special issue, the authors would like to encourage comparisons between units of the Iberian Peninsula that, as occurs in the Ossa Morena Zone and the Pyrenees, does not exhibit well-established relationships with the rest of the Iberian Massif. It was in some of these SW located units where Cecilio Quesada developed most of his long and fructiferous career. This work was funded by projects CGL2010-21298 and Consolider-Ingenio 2010, under CSD2006-00041 Topoiberia. Funding for A. M. came from Institut d'Estudis Andorrans.

\section{References}

Abad, A., 1987. Primera cita de arqueociátidos en Cataluña. Trabajos Museo Geología Seminario Barcelona 222, 10.

Aguilar, C., Liesa, M., Castiñeiras, P., Navidad, M., 2014. Late Variscan metamorphic and magmatic evolution in the eastern Pyrenees revealed by $\mathrm{U}-\mathrm{Pb}$ age zircon dating. J. Geol. Soc. 171 (2), 181-192. http://dx.doi.org/10.1144/jgs2012-086.
Álvaro, J.J., Bauluz, B., Clausen, S., Devaere, L., Gil Imaz, A., Monceret, E., Vizcaíno, D., 2014. Stratigraphic review of the Cambrian-Lower Ordovician volcanosedimentary complexes from the northern Montagne Noire, France. Stratigraphy 11 (1), 83-96.

Avigad, D., Gerdes, A., Morag, N., Bechstädt, T., 2012. Coupled U-Pb-Hf of detrital zircons of Cambrian sandstones from Morocco and Sardinia: implications for provenance and Precambrian crustal evolution of North Africa. Gondwana Res. 21 (2), 690-703. http://dx.doi.org/10.1016/j.gr.2011.06.005.

Ayora, C., Casas, J.M., 1986. Strabound As-Au mineralization in pre-Caradocian rocks form the Vall de Ribes, Eastern Pyrenees, Spain. Mineral. Deposita 21, 278-287.

Barca, S., Carmignani, L., Cocozza, T., Franceschelli, M., Ghezzo, C., Memmi, I., Minzoni, N., Pertusati, P.C., Ricci, C.A., 1987. The Caledonian events in Sardinia. In: Gee, D.G., Sturt, B.A. (Eds.), The Caledonian Orogen-Scandinavian and Related Areas. John Wiley ans Sons Ltd., pp. 1195-1199.

Casas, J.M., 2010. Ordovician deformations in the Pyrenees: new insights into the significance of pre-Variscan ('sardic') tectonics. Geol. Mag. 147 (05), 674-689. http://dx.doi. org/10.1017/S0016756809990756.

Casas, J.M., Fernández, O., 2007. On the Upper Ordovician unconformity in the Pyrenees: new evidence from the La Cerdanya area. Geol. Acta 5, 193-198.

Casas, J.M., Palacios, T., 2012. First biostratigraphical constraints on the pre-Upper Ordovician sequences of the Pyrenees based on organic-walled microfossils. Compt. Rendus Geosci. 344 (1), 50-56. http://dx.doi.org/10.1016/j.crte.2011.12.003.

Casas, J.M., Queralt, P., Mencos, J., Gratacós, O., 2012. Distribution of linear mesostructures in oblique folded surfaces: unravelling superposed Ordovician and Variscan folds in the Pyrenees. J. Struct. Geol. 44, 141-150. http://dx.doi.org/10.1016/j.jsg.2012.08.013.

Casas, J.M., Navidad, M., Castiñeiras, P., Liesa, M., Aguilar, C., Carreras, J., Hofman, M. Gärtner, A., Linnemann, U., 2015. The Late Neoproterozoic magmatism in the Ediacaran series of the Eastern Pyrenees: new ages and isotope geochemistry. Int. J. Earth Sci. 104 (4), 909-925. http://dx.doi.org/10.1007/s00531-014-1127-1.

Castiñeiras, P., Navidad, M., Liesa, M., Carreras, J., Casas, J.M., 2008. U-Pb zircon ages (SHRIMP) for Cadomian and Lower Ordovician magmatism in the Eastern Pyrenees: new insights in the pre-Variscan evolution of the northern Gondwana margin. Tectonophysics 461, 228-239. http://dx.doi.org/10.1016/j.tecto.2008.04.005.

Cavet, P., 1957. Le Paléozoïque de la zone axiale des Pyrénées Orientales Françaises entre le Roussillon et l'Andorre: étude stratigraphique et paléontologique. Librairie Polytechnique Ch. Béranger.

Cirés, J., Casas, J.M., Santanach, P., Muñoz, J.A., Fleta, J., Serrat, D., 1994. Mapa geológico de España (1: 50.000): Molló (n. 218). ITGE Madrid, España

Den Brok, S.W.J., 1989. Evidence for pre-Variscan deformation in the Lys Caillaouas area Central Pyrenees, France. Geol. Mijnb. 68, 377-380.

Díez-Fernández, R., Martínez Catalán, J.R., Gerdes, A., Abati, J., Arenas, R., FernándezSuárez, J., 2010. U-Pb ages of detrital zircons from the basal allochthonous units of NW Iberia: provenance and paleoposition on the northern margin of Gondwana during the Neoproterozoic and Paleozoic. Gondwana Res. 18, 385-399. http://dx. doi.org/10.1016/j.gr.2009.12.006.

Díez-Fernández, R., Catalán, J.R.M., Arenas, R., Abati, J., Gerdes, A., Fernández-Suárez, I. 2012. U-Pb detrital zircon analysis of the lower allochthon of NW Iberia: age constraints, provenance and links with the Variscan mobile belt and Gondwanan cratons. J. Geol. Soc. 169 (6), 655-665. http://dx.doi.org/10.1144/jgs2011-146169, 655-665.

Fernández-Suárez, J., Gutiérrez-Alonso, G., Jenner, G.A., Tubrett, M.N., 1999. Crusta sources in Lower Palaeozoic rocks from NW Iberia: insights from laser ablation UPb ages of detrital zircons. J. Geol. Soc. 156, 1065-1068. http://dx.doi.org/10.1144 gsjgs.156.6.1065.

Fernández-Suárez, J., Gutiérrez-Alonso, G., Jenner, G.A., Tubrett, M.N., 2000. New ideas on the Proterozoic-Early Palaeozoic evolution of NW Iberia: insights from U-Pb detrital zircon ages. Precambrian Res. 102 (3), 185-206. http://dx.doi.org/10.1016/S03019268(00)00065-6.

Fernández-Suárez, J., Gutiérrez-Alonso, G., Jeffries, T.E., 2002. The importance of alongmargin terrane transport in Northern Gondwana: insights from detrital zircon parentage in Neoproterozoic rocks from Iberia and Brittany. Earth Planet. Sci. Lett. 204, 75-88. http://dx.doi.org/10.1016/S0012-821X(02)00963-9.

Fernández-Suárez, J., Díaz García, F., Jeffries, T.E., Aas, R., Abati, J., 2003. Constraints on the provenance of the uppermost allochthonous terrane of the NW Iberian Massif: inferences from detrital zircon U-Pb ages. Terra Nova 15, 138-144. http://dx.doi.org/10. 1046/j.1365-3121.2003.00479.x.

Fernández-Suárez, J., Gutiérrez-Alonso, G., Pastor-Galán, D., Hofmann, M., Murphy, J.B. Linnemann, U., 2014. The Ediacaran-Early Cambrian detrital zircon record of NW Iberia: possible sources and paleogeographic constraints. Int. J. Earth Sci. 103 (5), 1335-1357. http://dx.doi.org/10.1007/s00531-013-0923-3.

Frei, D., Gerdes, A., 2009. Precise and accurate in situ U-Pb dating of zircon with high sample throughput by automated LA-SF-ICP-MS. Chem. Geol. 261 (3), 261-270. http://dx.doi.org/10.1016/i.chemgeo.2008.07.025.

Friedl, G., Finger, F., McNaughton, N.J., Fletcher, I.R., 2000. Deducing the ancestry of terranes: SHRIMP evidence for South America-derived Gondwana fragments in central Europe. Geology 28, 1035-1038.

García-Sansegundo, J., Alonso, J.L., 1989. Stratigraphy and structure of the southeastern Garona Dome. Geodin. Acta 3 (2), 127-134. http://dx.doi.org/10.1080/09853111. 1989.11105180.

Gehrels, G., 2012. Detrital zircon U-Pb geochronology: current methods and new opportunities. In: Busby, C., Azor, A. (Eds.), Tectonics of Sedimentary Basins: Recent Advances, pp. 45-62 http://dx.doi.org/10.1002/9781444347166.ch2.

Gil-Peña, I., Barnolas, A., Villas, E., Sanz-López, J., 2004. El Ordovícico Superior de la Zona Axial. Geología de España. SGE-IGME, Madrid, pp. 247-249.

Guitard, G., 1970. Le métamorphisme hercynien mésozonal et les gneiss oeillées du massif du Canigou (Pyrénées orientales). Orléans. Mémoires du BRGM 63353 p.

Guitard, G., Laumonier, B., Autran, A., Bandet, Y., Berger, G.M., 1998. Notice explicative, Carte géologique France (1:50.000), feuille Prades (1095). BRGM, Orléans (198pp.). 
Gutiérrez Marco, J.C Robardet, M., Rábano, I Sarmiento, G.N. San José Lancha, M.A. Herranz, P., Pieren Pidal, A.P., 2002. Ordovician. In: Gibbons, W.W., Moreno, T. (Eds.), The Geology of Spain. Geological Society of London, pp. 31-49.

Hartevelt, J.J.A., 1970. Geology of the upper Segre and Valira valleys, Central Pyrenees, Andorra, Spain. Leidse. Geol. Meded. 45, 167-236.

Kriegsman, L.M., Aerden, D.G.A.M., Bakker, R.J., den Brok, S.W.J., Schutjens, P.M.T.M., 1989 Variscan tectonometamorphic evolution of the eastern Lys-Caillaouas massif, Centra Pyrenees-evidence for late orogenic extension prior to peak metamorphism. Geol. Mijnb. 68, 323-333.

Laumonier, B., 1988. Les groupes de Canaveilles et de Jujols ("Paléozoïque inférieur") des Pyrénées orientales. Arguments en faveur de l'âge essentiellement cambrien de ces séries. HHercynica 4, 25-38.

Laumonier, B., Guitard, G., 1986. Le Paléozoïque inférieur de la moitié orientale de la Zone Axiale des Pyrénées. Essai de synthèse. Comptes rendus de l'Académie des sciences. Série 2, Mécanique, Physique, Chimie, Sciences de l'univers, Sciences de la Terre 302 (7), 473-478

Linnemann, U., Gehmlich, M., Tichomirowa, M., Buschmann, B., Nasdala, L., Jonas, P., Lützner, H., Bombach, K., 2000. From Cadomian subduction to Early Palaeozoic rifting: the evolution of Saxo-Thuringia at the margin of Gondwana in the light of single zircon geochronology and basin development (Central European Variscides, Germany). Geol. Soc. Lond., Spec. Publ. 179 (1), 131-153. http://dx.doi.org/10.1144/ GSL.SP.2000.179.01.10.

Linnemann, U., Pereira, F.M., Jeffries, T.E., Drost, K., Gerdes, A., 2008. The Cadomian Orogeny and the opening of the Rheic Ocean: the diacrony of geotectonic processes constrained by LA-ICP-MS U-Pb zircon dating (Ossa-Morena and Saxo-Thuringian Zones, Iberian and Bohemian Massifs). Tectonophysics 461, 21-43. http://dx.doi. org/10.1016/j.tecto.2008.05.002.

Ludwig, K.R., 2001. Users manual for Isoplot/Ex rev. 2.49. Berkeley Geochronology Center Special Publication No. 1a, pp. 1-56.

Llopis Lladó, N., 1965. Sur le Paléozoïque inférieur de l'Andorre. Bull. Soc. Geol. Fr. 7. 652-659.

Martí, J., Casas, J.M., Guillén, N., Muñoz, J.A., Aguirre, G., 2014. Structural and geodynamic constraints of Upper Ordovician volcanism of the Catalan Pyrenees. Gondwana 15.

Martínez Catalán, J.R., Fernández-Suárez, J., Jenner, G.A., Belousova, E., Díez Montes, A. 2004. Provenance constraints from detrital zircon U-Pb ages in the NW Iberian Massif: implications for Paleozoic plate configuration and Variscan evolution. J. Geol. Soc. 161, 461-473.

Maurel, O., Respaut, J.P., Monié, P., Arnaud, N., Brunel, M., 2004. U-Pb emplacement and ${ }^{40} \mathrm{Ar} /{ }^{39} \mathrm{Ar}$ cooling ages of the eastern Mont-Louis granite massif (Eastern Pyrenees, France). Compt. Rendus Geosci. 336 (12), 1091-1098. http://dx.doi.org/10.1016/j. crte.2004.04.005.

Meinhold, G., Morton, A.C., Avigad, D., 2013. New insights into peri-Gondwana paleogeography and the Gondwana super-fan system from detrital zircon U-Pb ages. Gondwana Res. 23 (2), 661-665. http://dx.doi.org/10.1016/j.gr.2012.05.003.

Muñoz, I.A., 1992. Evolution of a continental collision belt: ECORS-Pyrenees crustal balanced cross-section. Thrust Tectonics 235-246 http://dx.doi.org/10.1007/97894-011-3066-0_21.

Muñoz, J.A., Vergés, J., Martínez-Rius, A., Fleta, J., Cirés, J., Casas, J.M., Sàbat, F., 1994. Mapa geológico de España (1: 50.000): Ripoll (no 256). ITGE Madrid, España.

Navidad, M., Castiñeiras, P., Casas, J.M., Liesa, M., Suárez, J.F., Barnolas, A., Carreras, J. Gil-Peña, I., 2010. Geochemical characterization and isotopic age of Caradocian magmatism in the northeastern Iberian Peninsula: insights into the Late Ordovician evolution of the northern Gondwana margin. Gondwana Res. 17 (2) 325-337. http://dx.doi.org/10.1016/j.gr.2009.11.013.

Orejana, D., Merino Martínez, E., Villaseca, C., Andersen, T., 2015. Ediacaran-Cambrian paleogeography and geodynamic setting of the Central Iberian Zone: constraints from coupled U-Pb-Hf isotopes of detrital zircons. Precambrian Res. 261, 234-251. http://dx.doi.org/10.1016/j.precamres.2015.02.009.
Pereira, M.F., Chichorro, M., Solá, A.R., Silva, J.B., Sánchez-García, T., Bellido, F., 2011. Tracing the Cadomian magmatism with detrital/inherited zircon ages by in-situ U-Pb SHRIMP geochronology (Ossa-Morena Zone, SW Iberian Massif). Lithos 123, 204-217. http://dx.doi.org/10.1016/j.lithos.2010.11.008.

Pereira, M.F., Linnemann, U., Hofmann, M., Chichorro, M., Solá, A.R., Medina, I., Silva, J.B., 2012a. The provenance of Late Ediacaran and Early Ordovician siliciclastic rocks in the Southwest Central Iberian Zone: constraints from detrital zircon data on northern Gondwana margin evolution during the late Neoproterozoic. Precambrian Res. 192, 166-189. http://dx.doi.org/10.1016/j.precamres.2011.10.019.

Pereira, M.F., Solá, A.R., Chichorro, M., Lopes, L., Geres, A., Silva, J.B., 2012b. NorthGondwana assembly, break-up and paleogeography: U-Pb isotope evidence from detrital and igneous zircons of Ediacaran and Cambrian rocks of SW Iberia. Gondwana Res. 22, 866-881. http://dx.doi.org/10.1016/j.gr.2012.02.010.

Pillola, G.L., Piras, S., Serpagli, E., 2008. Upper Tremadoc-Lower Arenig? AnisograptidDichograptid fauna from the Cabitza Formation (Lower Ordovician, SW Sardinia, Italy). Rev. Micropaleontol. 51, 167-181. http://dx.doi.org/10.1016/j.revmic.2007.08. 002

Romer, R.L., Soler, A., 1995. U-Pb age and lead isotopic characterization of Au-bearing skarn related to the Andorra granite (central Pyrenees, Spain). Mineral. Deposita 30 (5), 374-383. http://dx.doi.org/10.1007/BF00202280.

Santanach, P., 1972a. Sobre una discordancia en el Paleozoico inferior de los Pirineos orientales. Acta Geol. Hisp. 7 (5), 129-132.

Santanach, P., 1972b. Estudio tectónico del Paleozoico inferior del Pirineo entre Cerdaña y el río Ter. Acta geológica hispánica 7 (2), 44-49.

Sanz-López, J., Gil-Peña, I., Valenzuela Ríos, J.I., 2002. Lower Paleozoic rocks from the Pyrenees: a synthesis. In: García-López, S., Bastida, F. (Eds.), Paleozoic Conodonts from Northern Spain. Publicaciones del Instituto Geológico y Minero de España, Cuadernos del Museo Geominero 1, Madrid, pp. 349-366.

Shaw, I., Gutiérrez-Alonso, G, Johnston, S.T. Galán, D.P. 2014. Provenance variability along the Early Ordovician north Gondwana margin: paleogeographic and tectonic implications of U-Pb detrital zircon ages from the Armorican Quartzite of the Iberian Variscan belt. Geol. Soc. Am. Bull. 126 (5-6), 702-719. http://dx.doi.org/10.1130/ B30935.1.

Sircombe, K.N., 2004. Age display: an EXCEL workbook to evaluate and display univariate geochronological data using binned frequency histograms and probability density distributions. Comput. Geosci. 30 (1), 21-31. http://dx.doi.org/10.1016/j.cageo.2003. 09.006

Stacey, J.T., Kramers, J.D., 1975. Approximation of terrestrial lead isotope evolution by a two-stage model. Earth Planet. Sci. Lett. 26 (2), 207-221.

Talavera, C., Montero, P., Poyatos, D.M., Williams, I.S., 2012. Ediacaran to Lower Ordovician age for rocks ascribed to the Schist-Graywacke Complex (Iberian Massif, Spain): evidence from detrital zircon SHRIMP U-Pb geochronology. Gondwana Res. 22 (3), 928-942. http://dx.doi.org/10.1016/j.gr.2012.03.008.

Talavera, C., Poyatos, D.M., Lodeiro, F.G., 2015. SHRIMP U-Pb geochronological constraints on the timing of the intra-Alcudian (Cadomian) angular unconformity in the Central Iberian Zone (Iberian Massif, Spain). International Journal of Earth Sciences 1-19 http://dx.doi.org/10.1007/s00531-015-1171-5.

Vilà, M., Pin, M., Liesa, M., Enrique, P., 2007. LPHT metamorphism in a late orogenic transpressional setting, Albera Massif, NE Iberia: implications for the geodynamic evolution of the Variscan Pyrenees. Journal of Metamorphic Geology 25, 321-347. http://dx.doi.org/10.1111/j.1525-1314.2007.00698.x.

Williams, I.S., Fiannacca, P., Cirrincione, R., Pezzino, A., 2012. Peri-Gondwanan origin and early geodynamic history of NE Sicily: a zircon tale from the basement of the Peloritani Mountains. Gondwana Res. 22 (3), 855-865. http://dx.doi.org/10.1016/i. gr.2011.12.007

Zwart, H.J., 1979. The geology of the Central Pyrenees. Leid. Geol. Meded. 50, 1-74. 